Public Administration and was a scholar in residence there from 1980 to 1982.

He was also a member of many professional associations, such as the APSA, the American Society for Public Administration, and the Federation of American Scientists.

A native of Pasadena, California, Stover received his undergraduate degree in 1951 and his master's degree in political science from Stanford University in 1955.

Stover died on February 19, 2010, in Silver Spring, Maryland, from congestive heart failure. He is survived by his wife of 36 years, Jacqueline Kast Stover of Silver Spring; three children from his first marriage, Matthew J. Stover of Chester, New Hampshire; Mary S. Marker of Columbia, Maryland; and Claire S. Herrell of Harpers Ferry, West Virginia; and seven grandchildren.

\section{NEAL TATE}

C. Neal Tate, born October 17, 1943, passed away September 13, 2009, in Nashville, Tennessee. At the time of his death, Neal was the Alexander Heard Distinguished Service Professor, professor of political science, and professor of law at Vanderbilt University, where he had also served as chair of the political science department since 2003. He had previously served on the faculty of the University of North Texas from 1970 through 2003. With a deep sense of sadness, his colleagues and friends at both institutions say goodbye to a beloved friend, teacher, and colleague. Neal's passing has been a great loss for many people around the country and around the world. His contributions were many, and while we will no longer have the benefit of his kindness, keen intellect, and fine sense of humor, we will continue to benefit from his many legacies.

Neal was born in Gastonia, North Carolina, the oldest of the four sons of Chester Marshall Tate and Pearl Whitaker Tate. He earned his BA cum laude from Wake Forest in 1965, and received his MA and Ph.D. in political science from Tulane University in 1970. At Tulane, Neal met and married his wife of 43 years, Carol McKenzie Tate. Neal built a prominent scholarly career, publishing visible and important research on international human rights and the workings of judicial institutions around the world. These contributions added greatly to our understanding of the law and how legal institutions advance the prospects for democracy and the freedoms associated with it.
When Neal embarked on his academic career, there was little genuine scholarly knowledge of how judicial systems worked, especially in less developed and less democratic nations. Yet Neal recognized that judicial institutions can shape the quality of life enjoyed by the people in these countries in important ways. He addressed this lacuna by collecting new data that would shed light on these vital processes. His efforts gave life to a new subfield known as "comparative courts." With both respect and affection, younger scholars often refer to Neal as "the godfather" of the field. This area of scholarship proved to be his life's work, and his efforts continued up to the day he died. Prior to his death, Neal had just received additional funding from the National Science Foundation to study judicial systems in Latin America, was working on two books, and had just published an article in one of our leading journals.

Neal's interest in advancing the quality of people's lives, which motivated his collection of all these valuable data, also led him to study directly the advancement of human rights. As someone who believed that political context matters, he hypothesized that domestic disputes in a country would shape the prospects for human rights. His instincts proved sound, showing that repression, for instance, did indeed have serious effects on human rights for people around the globe. Neal then started to explore whether international agreements affected human rights, and marshaled evidence that showed his judgment was on target.

Neal's research career is a wonderful testimony to the tireless efforts of a scholar interested in unpacking the workings of fundamental legal processes that touch on the prospects for democratic government. His work will continue to be cited, and his data will continue to be analyzed. His intellectual legacy will endure.

Neal was also a deeply committed and successful teacher who shared his excitement about research with all his students. As a mentor of graduate students he led his students to important problems and then helped develop their research methodology. As a result, his students from both the University of North Texas and Vanderbilt went on to great careers.

As a faculty member, Neal began his teaching career at the University of North Texas in 1970, where he served as chair of the political science department from 1980 to 1986 . He became a Regents Professor and later served as dean of the Robert B. Toulouse School of Graduate Studies. Neal played a central role in modernizing and building the political science department and programs at UNT. Under his leadership, both formal and informal, the department transformed itself from a service department into a well-regarded research and graduate training institution. Neal's efforts actively shaped the department's professional standards, curriculum, governance, graduate program, and external recognition. He was aleader, a model colleague, and a generous mentor, and throughout his 33 years at UNT, did yeoman departmental and university service.

His colleagues at Vanderbilt also knew of Neal as a gifted administrator. His administrative experience at North Texas proved helpful when he arrived in Nashville. The department was in trouble. The size of the faculty had shrunk from 18 to fewer than 10 , and the graduate program, as a result, was struggling. Neal was given the support and resources to rebuild, and he used both with care, shrewdness, and his own special style, which is best characterized as understated aggressiveness. He used his keen understanding of the discipline of political science to develop and execute a plan to regain national visibility as a top department. And so he did. By the time of his death, the Vanderbilt department had grown far larger than it had ever been in its history and had also grown in quality and in spirit, with over 25 faculty members and a robust group of over 40 graduate students.

Colleagues at both Vanderbilt and North Texas recall that Neal had the highest professional standards but was among the least confrontational of people. He had the unique ability to be able to take a stand and push for excellence, but he never had to fall back on the strategy of "breaking eggs to make an omelet." Rather, the "omelet" he made involved no breaking of eggs (or anything else), only building, nurturing, and finding a way of persuading others of the correctness and wisdom of his wellformulated and professional standards.

Our only regret is that Neal left us far too soon. He faced adversity in the same way he enjoyed the many successes and accomplishments in his life-quietly, without public displays of emotion. But his spirit, generosity, vision, and professionalism gave rise to new norms of excellence that shaped two political science departments and made great contributions to two important areas of scholarship. 
His passing is a profound one for his beloved wife Carol, daughter Erin, and sonin-law Scott, as well as his many students, friends, and colleagues at Vanderbilt, North Texas, and around the world and in the profession of political science. We are all lessened by his absence but strengthened immeasurably by his having touched our lives. Vanderbilt and North Texas are better places because of his time on our campuses and in our communities.

John Booth University of North Texas John Geer

Vanderbilt University Mitch Seligson

Vanderbilt University

\section{ROBERT C. TUCKER}

I cannot be entirely objective about the life and death of Robert Charles Tucker, who died, at age 92, at his home in Princeton on July 29. During the course of 50 years, Bob Tucker was my mentor, colleague, and very dear friend. He was the best man at my wedding to Katrina (Katia) vanden Heuvel, and I gave my oldest daughter, from a previous marriage, his family name as her middle name: Alexandra Tucker Cohen.

If I had not met Professor Tucker at Indiana University in 1960, when I was a young student, Russia probably would not have become the supreme subject and profession of my life. Certainly, I would not have written a biography of Bukharin, because it was Bob who pointed me toward missed alternatives in Russian and Soviet history, including the Bukharinist alternative. With his death, I have lost a large and essential part of my own life.

Nonetheless, I think I am being objective in stating that Robert C. Tucker was the preeminent and most influential American, possibly Western, scholar of Russia of his times. His scholarly influence ranged across several academic fields, from philosophy, political science, leadership studies, and comparative theory to history, and it inspired several generations of scholars well beyond the orbit of his own students at Indiana and Princeton universities.

Bob's achievements as a scholar were due, in large part I think, to four of his personal attributes. First, unlike many American academics, he was not merely a specialist but an intellectual in the fullest sense. Before first encountering Russia while serving in the U.S. embassy in Moscow during World War II, Bob was a graduate student in philosophy at Harvard University. His first book was not about Russia, but was rather a profound reinterpretation of Marx's thought as an outgrowth of Hegelianism, Philosophy and Myth in Karl Marx. Broad philosophical perspectives, not ideology, shaped Bob's subsequent thinking about politics and history as well.

Second, also unlike many Western specialists today, Bob began to read widely and deeply in Russian history while living in Moscow in the 1940s and 1950s, and he continued to do so throughout his life. As a result, he always viewed Soviet Russia in the larger context of its pre-1917 traditions, several of which, he argued, continued to shape Soviet developments for decades to come. (About this, he once had a highly publicized and fruitful quarrel with Aleksandr Solzhenitsyn, which aroused considerable indignation in that great novelist and among his followers.)

Third, and crucially, Stalinism was not an abstraction for Bob, but a phenomenon he experienced personally when he and his Russian wife, Evgeniia Pestretsova, whom he married in Moscow in 1946, were forbidden to leave the country together until after Stalin died in 1953. During those seven years of growing Soviet-American cold war, they were in constant danger of falling victim to the despot's renewed and xenophobic terror. From that intense experience came Bob's lifelong determination to explain Stalinism and, at its core, the Vohzd himself, as manifested in his definitive two-volume biography of Stalin.
But fourth, despite that harrowing experience, Bob loved Russia. It became his second Rodina, as it later became for me, and he never doubted Russia's capacity for fundamental reform, even democratic change. Not surprisingly, in the late 1960s, Andrei Sakharov was one of the Russians Bob most admired, and later, Gorbachev's effort to carry out a democratic reformation of the Soviet system was confirmation of what Bob had long thought possible. Too many Western specialists and other media commentators believe that Russia can never escape its authoritarian past, a shallow, demeaning view that has grown even more widespread in recent years. Bob, on the other hand, repeatedly told his students, "When thinking about Russia's future, never say never."

Apart from members of his family, I may have been the person closest intellectually to Robert Tucker and most influenced by him, but in the hours and days following his death, many of his devoted former students were immediately in contact with each other by way of e-mail or telephone. Our discussion was, of course, an expression of our mourning, but also of our gratitude for the privilege of having known him as a teacher and a man. All of us knew who we had lost, someone much more important and special than suggested even in the admiring obituaries in the New York Times and the Washington Post.

Boris Pasternak once remarked that an afterlife is how a person is remembered. The afterlife of Robert Charles Tucker will be at least as long and exemplary as was his earthly life. His writings will long survive him, not only the essential two-volume biography of Stalin, but also the seminal essays collected in his books The Soviet Political Mind and The Marxian Revolutionary Idea. Certainly, we, his students and friends, will never forget him or outlive his influence. Nor, I think, will our own students.

Stephen Cohen (Stiven Koen) New York University 